\title{
ВНУТРІШНІЙ ОСВІТНІЙ АУДИТ ЯК ЧИННИК ВПЛИВУ НА ЯКІСТЬ ОСВІТНЬОГО ПРОЦЕСУ В ЗАКЛАДІ ЗАГАЛЬНОЇ СЕРЕДНЬОЇ ОСВІТИ
}

\author{
Григораш В. В., Ph. D \\ Хлєбнікова Т. М., Ph. D

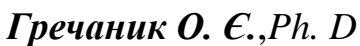

Україна, м. Харків, Харківський національний педагогічний університет імені Г. С. Сковороди

DOI: https://doi.org/10.31435/rsglobal_ws/30082018/6071

\section{ARTICLE INFO}

Received: 21 July 2018

Accepted: 21 August 2018

Published: 30 August 2018

\section{KEYWORDS}

internal audit, audit centre,

system of general secondary

education institution,

qualimetric model.

\begin{abstract}
The article outlines the main approaches to creating an internal audit system of general secondary education institution. Functions, objects and subjects of the internal audit system are generalized. Particular attention is paid to the creation of special structural subdivisions of the system of internal audit of the institution of general secondary education. In particular, the organizational principles of the establishment of a quality audit center are described. A new model of internal audit is presented: a school quality management system. The process of designing and algorithm of the school system of quality management education is described. The results of researches about readiness of heads of educational establishments for updating of system of internal audit are presented. The criteria for evaluating the readiness of the educational institution and its management for the implementation of the programs of internal audit are proposed. Qualimetric model of internal audit quality assessment in the institution of general secondary education is provided.
\end{abstract}

Citation: Григораш В. В., Хлєбнікова Т. М., Гречаник О. С. (2018) Vnutrishnii Osvitnii Audyt yak Chynnyk Vplyvu na Yakist Osvitnoho Protsesu v Zakladi Zahalnoi Serednoi Osvity. World Science. 8(36), Vol.3. doi: 10.31435/rsglobal_ws/30082018/6071

Copyright: (C) 2018 Григораш В. В., Хлєбнікова Т. М., Гречаник О. С. This is an open-access article distributed under the terms of the Creative Commons Attribution License (CC BY). The use, distribution or reproduction in other forums is permitted, provided the original author(s) or licensor are credited and that the original publication in this journal is cited, in accordance with accepted academic practice. No use, distribution or reproduction is permitted which does not comply with these terms.

Вступ. Реформування галузі освіти в Україні зумовлює зміни в управлінні закладами освіти, зокрема, й контрольно-аналітичній діяльності їхніх керівників. Законом України «Про освіту» визначено сутність поняття «якість освітньої діяльності». Мова йде про відповідність рівня організації освітнього процесу встановленим законодавством вимогам. Уперше в нормативних документах 3'явилося поняття «аудит». Зокрема, інституційний аудит визнано елементом системи зовнішнього забезпечення якості освіти. У той же час розвиток світової системи освіти пов'язаний із упровадженням системи освітнього аудиту, який можна здійснювати у двох формах - внутрішній і зовнішній. Для керівника закладу освіти важливо створити систему внутрішнього освітнього аудиту, яка забезпечить надходження релевантної інформації про освітній процес та його результати, необхідної для прийняття раціональних управлінських рішень. Зазначимо, що сучасний підхід до управління закладом освіти передбачає відповідність системи управління вимогам сучасного менеджменту (раціональність, валідація освітніх процесів, об'єктивність тощо). Отже, розвиток системи внутрішнього освітнього аудиту в закладі загальної середньої освіти є суттєвим напрямом реформування освітньої галузі.

Контрольно-аналітичній діяльності керівників закладів освіти постійно приділяли увагу провідні науковці в галузі освіти. Останні дослідження в цій царині знань присвячені інституціоналізації освітньої (зокрема управлінської) діяльності, упровадженню технології педагогічної експертизи, використанню кваліметричного підходу в оцінюванні якості освіти, 
освітнього процесу, професійної компетентності педагогів і керівників закладів освіти [2, 3, 4, 7].

Метою цієї статті є визначення основних підходів до створення системи внутрішнього аудиту в закладі загальної середньої освіти та критеріїв оцінювання готовності закладу освіти i його керівництва до реалізації програм внутрішнього аудиту.

Результати дослідження. Термін «аудит» традиційно використовували в економіці відносно бухгалтерських документів. Проте останнім часом цей термін широко використовують у галузі освіти, що пов'язано зі спробою створення системи управління якістю освіти, орієнтованою на міжнародні стандарти серії ISO, TQM.

У цих стандартах визначено такі вимоги, як:

- перевірка всіх аспектів діяльності та процесів системи якості закладу освіти;

- планування аудитів;

- документування результатів перевірки;

- компетентність аудиторів;

- проведення за результатами аудитів аналізу системи якості з боку адміністрації; своєчасне виправлення невідповідностей.

Ми визначаємо внутрішній аудит як адміністрування, що забезпечує оцінку освітньої діяльності та якості освіти загалом і за окремими структурними підрозділами, напрямами, суб'єктами педагогічного процесу.

Цей вид діяльності має низку суттєвих характеристик:

- незалежність (створення організаційної структури внутрішнього аудиту, якій надані достатні для забезпечення самостійної діяльності повноваження);

- об'єктивність (індивідуальні якості внутрішнього аудитора - компетентність, неупередженість в оцінках і висновках та використання методик, які дозволяють послабити суб'єктивність аудитора);

- результативність (надання замовникам аудиту об’єктивного аналізу освітньої системи, процесів, результатів і розробляння консультацій із питань підвищення ефективності діяльності).

3 організаційної точки зору, аудит - це:

- діяльність із надання незалежних та об'єктивних оцінок і консультацій, спрямованих на вдосконалення діяльності закладу освіти;

- незалежне оцінювання результатів освітнього процесу;

- моніторинг освітньої діяльності та іiі результатів, установлення відповідності нормативним вимогам.

Як відомо, аудит може бути операційним, фінансовим і на відповідність вимогам. Зупинимося на останньому виді аудиту. Під час аудиту відповідності встановлюють ступінь, 3 якою система якості зрозуміла, упроваджена й дотримується персоналом (фактичне виконання персоналом вимог, установлених у документації на відповідність якості освітньої діяльності).

Мета аудиту на відповідність вимогам - перевірка дотримання персоналом правил і процедур, визначених вищим керівництвом. Перевірки на відповідність призначені для виявлення дотримання організацією конкретних правил, законів, пунктів договорів, які впливають на результати діяльності.

Основними об’єктами внутрішнього аудиту є рішення окремих функціональних завдань управління, розробляння й перевірка інформаційних систем організації. Розглянемо різні визначення саме внутрішнього аудиту.

За документами Міжнародного інституту внутрішніх аудиторів, внутрішній аудит - це незалежна діяльність в організації з перевірки й оцінювання іiі роботи в іiї інтересах.

За Міжнародним стандартом аудиту 610 («Розгляд роботи внутрішнього аудиту»), внутрішній аудит - це діяльність підрозділу клієнта 3 оцінювання роботи суб'єкта, перевірки та моніторингу адекватності й ефективності систем бухгалтерського обліку і внутрішнього контролю.

За іншими міжнародними стандартами, внутрішній аудит - це організована суб'єктом, діюча в інтересах керівництва, регламентована внутрішніми документами система контролю.

В організаційно-правовому аспекті аудит регламентований нормативними актами різного рівня.

До першого рівня відноситься Закон України «Про освіту». Ним, зокрема, визначено основні повноваження керівника закладу освіти, серед яких: забезпечення організації освітнього процесу та здійснення контролю за виконанням освітніх програм; організація функціонування внутрішньої системи забезпечення якості освіти; забезпечення умов для здійснення дієвого та відкритого громадського контролю за діяльністю закладу освіти.

Крім того, передбачено, що внутрішня система забезпечення якості освіти може включати стратегію (політику) та процедури забезпечення якості освіти; оприлюднені критерії, 
правила і процедури оцінювання здобувачів освіти; оприлюднені критерії, правила і процедури оцінювання педагогічної діяльності; оприлюднені критерії, правила та процедури оцінювання управлінської діяльності керівних працівників закладу освіти; інші процедури й заходи, що визначаються спеціальними законами або документами закладу освіти. Таким чином, реалізація повноважень керівника закладу освіти зумовлює наявність системи внутрішнього аудиту.

До документів другого рівня можуть бути віднесені укази й розпорядження Президента України, постанови Кабінету Міністрів України, накази Міністерства освіти і науки України, що встановлюють основні засади діяльності закладів освіти.

Як документи третього рівня можна розглядати правила (стандарти) освітньої діяльності, розроблені на регіональному рівні.

Четвертий рівень - це нормативні акти, розроблені власне в закладі освіти (як правило, затверджені керівником закладу освіти): положення, інструкції, правила, плани, графіки, розклади, розпорядження, накази тощо.

Для здійснення внутрішнього аудиту використовують різні організаційні форми.

Формування власної служби внутрішнього аудиту передбачає його здійснення власними силами організації, чому сприяє хороша поінформованість співробітників про внутрішню структуру компанії та галузеві особливості діяльності.

Аутсорсинг передбачає повне або часткове передання функцій внутрішнього аудиту стороннім аудиторам (експертам) або зовнішньому консультанту.

Ко-сорсинг передбачає, що всередині організації створюють органи внутрішнього аудиту, але в деяких випадках можна залучати експертів сторонніх організацій або зовнішніх консультантів, іншими словами, ко-сорсинг є частковим аутсорсингом.

Система внутрішнього аудиту необхідна для постійного вдосконалення шкільної системи забезпечення якості освіти. Аудит уважають результативним, якщо він забезпечує вільний i неупереджений підхід до прийняття рішень; виявлення можливостей для вдосконалення; поліпшення проходження інформації; посилення мотивації; оцінку можливості наявної системи.

Ефективність внутрішнього аудиту, якість освітнього процесу забезпечують створенням надійних організаційно-управлінських механізмів оцінювання.

Для цього в закладі освіти розробляють задокументовану методику «внутрішній аудит». Документами аудиту можуть бути:

- програма аудиту;

- план внутрішнього аудиту системи якості;

- опитувальні аркуші;

- протоколи відповідності стандартам;

- звіти про аудит;

- плани корекції та запобіжних дій.

Під програмою аудиту розуміють сукупність одного або декількох аудитів, запланованих на конкретні терміни і спрямованих на досягнення певних цілей. Відповідно до встановленої програми аудитів (перевірок) можна періодично проводити аудити різних підрозділів закладу освіти, різних процесів і видів діяльності, результатів діяльності або загальні системні аудити системи якості закладу освіти (атестація).

Для систематичного аудіювання рекомендують розробити стандартну форму, яка має включати в себе такі складники:

- мета аудиту;

- об'єкт аудиту (конкретні підрозділи, види діяльності, напрями, персонал тощо);

- суб'єкт аудиту (аудиторська група, яка проводить аудит);

- нормативні документи, за якими здійснюють перевірку (перераховують конкретні документи і критерії, на відповідність яким проводять перевірку);

- хід перевірки (вказують основні види діяльності під час перевірки, терміни виконання);

- основні методики та технології, що використовують для перевірки;

- інструментарій (анкети, опитувальні аркуші, кваліметричні моделі, протоколи тощо).

Для проведення внутрішніх аудитів якості освіти створюють спеціальний структурний підрозділ. Таким структурним підрозділом може стати центр аудиту якості освіти [7].

Метою роботи центру аудиту якості освіти є підвищення якості освіти.

Функції центру аудиту якості освіти:

- методична та консультаційна підтримка в процесі розробляння концепції впровадження принципів і методів менеджменту якості в закладі освіти; 
- розробляння гарантій якості, підготовка до видання й поширення навчальнометодичних матеріалів із питань менеджменту якості освіти (методичні вказівки та рекомендації щодо побудови й упровадження системи якості освітньої діяльності, посібники, курси лекцій, підручники, компакт-диски тощо);

- організація і проведення семінарів, циклів лекцій, курсів підвищення кваліфікації та додаткової освіти у сфері оцінювання якості освітнього процесу;

- методична й консультативна допомога в роботі зі створення, упровадження й удосконалення системи якості освіти (розробляння методик, типових форм документів, форм анкет для різних груп споживачів тощо);

- організація і проведення досліджень із проблем оцінювання якості освітнього процесу в закладі освіти;

- організація і проведення педагогічних вимірювань якості освіти;

- проведення моніторингу задоволеності педагогів, співробітників закладу освіти;

- здійснення моніторингу якості освітнього процесу;

- організація консультацій педагогів із питань проектування й упровадження системи якості освіти.

Основними вимогами до аудиторів є такі: бездоганна чесність; незалежність; відповідна професійна підготовка; використання сучасних контрольно-оцінних засобів і процедур.

Внутрішніх аудиторів призначають наказом директора. Внутрішні аудитори не можуть перевіряти свою власну діяльність. Аудит може проводити один аудитор або група аудиторів. Керівником групи аудиторів є головний аудитор.

Також загальними вимогами до внутрішніх аудиторів є наявність вищої освіти й досвіду роботи не менше 3-х років; наявність спеціальної підготовки 3 проведення внутрішніх аудитів або сертифіката внутрішнього аудитора; знання вимог нормативних документів; уміння встановлювати особисті контакти, комунікабельність, врівноваженість, уміння володіти собою; уміння аналітично і гнучко мислити; уміння усно й письмово висловлювати свої думки, тактовність, працездатність.

Внутрішні аудитори мають відповідально підходити до збереження конфіденційної інформації, якщо вона є. Внутрішній аудитор несе відповідальність у рамках своєї діяльності за виконання плану аудиту, достовірність і об’єктивність інформації з внутрішнього аудиту.

Центр аудиту якості освіти виконує комплекс функцій щодо забезпечення й контролю якості освіти: сервісну, діагностичну, компенсаторну, прогностичну, навчальну, консалтингову та консультативну.

Сервісна функція полягає в забезпеченні методичного, технологічного, інформаційного супроводу системи управління якістю освіти; здійсненні збирання, обробляння, аналізування, зберігання і представлення інформації про якість освітньої діяльності.

Діагностична функція включає вивчення й аналізування якості освітнього процесу, постійне відстеження, оцінювання його проміжних результатів, факторів, що вплинули на них, а також прийняття управлінських рішень із регулювання й коригування відповідно до прогнозованих результатів.

Компенсаторна функція, що реалізується на основі діагностичної, спрямована на розробляння рекомендацій i пропозицій на адресу структурних підрозділів закладу освіти 3 оцінювання якості засвоєння школярами основних освітніх програм.

Прогностична функція пов'язана 3 розроблянням випереджальних конструктивних моделей розв’язання проблем, що виникають в освітній діяльності.

Навчальна функція має на меті участь центру аудиту якості освіти у внутрішній системі підвищення кваліфікації з питань гарантії якості освіти.

На думку Б. Житника, доцільним є створення шкільної системи управління якістю освіти (ШСУЯО) [3].

ШСУЯО розглядають як сукупність суб'єктів (органів, що управляють) та об’єктів управління, функціональних регламентів, методів, засобів і заходів, спрямованих на проектування, реалізацію, забезпечення й підтримку такого рівня шкільних процесів, який відповідає вимогам держави та споживачів освітніх послуг.

Під час створення ШСУЯО основним завданням адміністрації закладу освіти $\epsilon$ створення служби якості (далі - СЯ 3О). Для розв’язання цього завдання необхідно:

- сформувати управлінську команду служби якості;

- розробити план створення й упровадження ШСУЯО;

- розробити й упровадити організаційну структуру ШСУяО.

Створена в закладі освіти служба має зосередитися на послідовному розв'язанні таких завдань: 
1) розробити нову функціональну схему надання освітніх послуг зі вказівкою обов'язків, завдань і регламентів діяльності всіх підрозділів, що входять до служби якості, а також інших підрозділів, що прямо або частково впливають на якість освітніх послуг;

2) розробити пропозиції щодо роботи з персоналом закладу (підвищення кваліфікації та проходження процедур атестації);

3) розробити документацію ШСУЯО, включаючи необхідні форми та записи, документовані процедури, керівництво якістю;

4) упорядкувати робочі процеси в закладі освіти, визначити вимірювані критерії (характеристики, параметри й індикатори) якості, методи й інструментарій їх виміру та збирання інформації.

Основними функціями служби якості закладу є:

- активна взаємодія із замовниками та споживачами освітніх послуг;

- безпосереднє керівництво ШСУЯО;

- організація діяльності з поліпшення якості освіти;

- навчання й мотивація персоналу спільно з іншими структурами ШСУ ЯО;

- проектування процесу надання освітніх послуг;

- проведення різних моніторингових операцій із визначення якості освітнього процесу та його результатів;

- методична та консультаційна підтримка робіт із упровадження методів управління якістю й розробляння документації в структурних підрозділах закладу освіти;

- збирання й аналізування інформації про якість освітніх послуг, які надає заклад освіти;

- підготовка пропозицій щодо усунення невідповідностей, підвищення кваліфікації та мотивації персоналу, поліпшення матеріальної бази й загального управління закладом і якістю освіти;

- доведення розроблених пропозицій до адміністрації закладу.

Для того щоб ШСУЯО функціонувала злагоджено під час координації діяльності всіх підрозділів закладу освіти, у кожному підрозділі призначають працівників (групи якості), які за своїм функціоналом відповідають за проведення заходів, спрямованих на забезпечення якості освіти.

Група якості - це робоча група, що об’єднує працівників одного або декількох підрозділів закладу освіти.

Групи якості здійснюють свою діяльність за двома напрямами:

1) проведення планових заходів служби якості закладу освіти;

2) визначення проблем, яким слід приділити першочергову увагу, і методів виявлення сильних та слабких сторін у реалізації освітньої програми.

Основною цільовою установкою для груп якості $є$ поліпшення стану комунікацій між педагогічними працівниками й адміністрацією закладу освіти. Кожна група працює під керівництвом одного з членів адміністрації.

У процесі проектування ШСУЯО відбувається формування нормативних, організаційних, методичних і критеріальних засад для здійснення діяльності щодо досягнення необхідної якості. Завдяки проектуванню система управління якістю отримує своє інституціональне оформлення.

Етапами проектування є:

1) установлення потреб та очікувань замовників (споживачів) й інших зацікавлених сторін. Разом із державними освітніми стандартами результати першого етапу є основою для розробляння основної освітньої програми закладу освіти. У межах освітніх стандартів гарантовано загальну доступність освіти.

Варіативна частина робочого навчального плану закладу загальної середньої освіти, яка по суті є «обличчям школи», повною мірою має бути зорієнтованою на запити безпосередніх споживачів освітніх послуг. Для їі складання закладу освіти вкрай важливо ідентифікувати 3 усіх потенційних споживачів тих, хто є споживачем повного пакету освітніх послуг школи. Саме під них і задаватиметься «планка» якості освіти. При цьому робочий навчальний план $\epsilon$ основним об'єктом управління якістю освіти;

2) визначення принципів i механізмів, спрямованих на постійне поліпшення функціонування системи управління якістю. Закладу необхідно постійно підвищувати результативність ШСУЯО. Основним принципом поліпшення є формулювання та постійне наслідування політики й цілей у галузі якості. До головних механізмів можна віднести:

- мотивуючу роль результатів вимірів та аудитів;

- об’єктивний і результативний аналіз;

- коригувальні й попереджувальні дії; 
3) розробляння політики та цілей закладу освіти в галузі якості освіти. Потреби закладу відображаються в його політиці, що формулюється як місія, і в цілях, що закріплюються в локальних актах закладу освіти. Такі документи існують під різними назвами: Концепції та Стандарти якості, Декларація про якість тощо;

4) установлення процесів і відповідальності, необхідних для досягнення цілей у галузі якості. Це важливий етап проектування ШСУЯО, оскільки в процесі оцінювання ефективності системи управління якістю необхідно отримати відповіді на чотири основні питання:

- чи виявлений і чи визначений відповідним чином процес;

- $\quad$ чи розподілена відповідальність між членами адміністрації та педагогічними працівниками закладу освіти для реалізації процесу;

- $\quad$ чи впроваджені та підтримуються в робочому стані процедури в процесі;

- $\quad$ чи є ефективним процес щодо досягнення необхідних результатів?

Якщо під час цього етапу всі дії здійснені правильно, то можна впевнено стверджувати, що заклад освіти може функціонувати в оптимальному режимі;

5) установлення й визначення необхідних ресурсів і забезпечення ними для досягнення цілей у галузі якості освіти. У системі управління якістю ресурси, у першу чергу, необхідні для підтримки іiі працездатності, а також для постійного підвищення іiі результативності. До кадрових ресурсів, ресурсів інфраструктури й до ресурсів, що забезпечують освітній процес, висувають особливі вимоги. Вони є основою структури стандарту якості освіти, який приймається за еталон;

6) розробляння нормативів якості освіти, методів та інструментарію для виміру результативності й ефективності кожного процесу. Нормативи якості $є$ переліками критеріїв, орієнтованих на задоволення споживачів освітніх послуг;

7) розробляння процедур моніторингу освітнього процесу на основі встановлених методів та інструментарію. За змістом розробляння процедур моніторингу освітнього процесу вимагає розробляння ефективної шкільної системи оцінки якості освіти;

8) визначення засобів, необхідних для попередження ризиків, що виникають під час реалізації освітньої програми. Основним продуктом, який реалізує заклад освіти, є його освітня програма. Щоб мінімізувати можливі ризики, які призводять до погіршання якості освіти, освітня програма має збалансовано враховувати вимоги державних освітніх стандартів, запити споживачів і потреби самих працівників закладу. Ефективним засобом попередження ризиків $\epsilon$ процедура корекції, яка усуває причини невідповідності в інтересах усіх зацікавлених сторін. Якщо ж невідповідності обумовлені об'єктивними причинами та не можуть бути усунені шляхом корекції, то необхідно приймати вольові управлінські рішення, спрямовані на попередження або мінімізацію можливих негативних наслідків.

Аналіз літератури й управлінського досвіду дозволяє визначити основні критерії ефективності системи внутрішнього аудиту в закладі загальної середньої освіти. Ми представимо їх у вигляді кваліметричної моделі (табл. 1).

Таблиця 1. Оцінка якості внутрішнього аудиту в закладі загальної середньої освіти

\begin{tabular}{|c|c|c|c|}
\hline Параметри & Вагомість & Критеріï & Вагомість \\
\hline 1 & 2 & 3 & 4 \\
\hline \multirow[t]{3}{*}{$\begin{array}{l}\text { Нормативне } \\
\text { забезпечення }\end{array}$} & \multirow[t]{3}{*}{0,2} & $\begin{array}{l}\text { 1. Наявність бази чинних нормативних документів } \\
\text { в галузі освіти }\end{array}$ & 0,4 \\
\hline & & $\begin{array}{l}\text { 2. Наявність та якість внутрішньої системи } \\
\text { нормативних документів у сфері внутрішнього } \\
\text { аудиту }\end{array}$ & 0,4 \\
\hline & & $\begin{array}{l}\text { 3. Наявність пакету документів щодо створення } \\
\text { шкільної системи управління якістю освіти } \\
\text { (центру аудиту якості освіти тощо) та їх } \\
\text { відповідність чинному законодавству }\end{array}$ & 0,2 \\
\hline \multirow{5}{*}{$\begin{array}{l}\text { Методичне } \\
\text { забезпечення }\end{array}$} & \multirow[t]{5}{*}{0,1} & 1. Якість програми аудиту & 0,3 \\
\hline & & 2. Планування внутрішнього аудиту системи якості & 0,1 \\
\hline & & $\begin{array}{l}\text { 3. Наявність і якість інструментарію внутрішнього } \\
\begin{array}{l}\text { аудиту (опитувальні аркуші; протоколи } \\
\text { відповідності стандартам тощо) }\end{array}\end{array}$ & 0,3 \\
\hline & & 4. Наявність і якість звітності про аудит & 0,1 \\
\hline & & $\begin{array}{l}\text { 5. Рівень аналізу отриманих результатів, наявність і } \\
\text { якість планів корекції та запобіжних дій }\end{array}$ & 0,2 \\
\hline
\end{tabular}


Продовження таблиці 1

\begin{tabular}{|c|c|c|c|}
\hline 1 & 2 & 3 & 4 \\
\hline \multirow[t]{5}{*}{$\begin{array}{l}\text { Технологічне } \\
\text { забезпечення }\end{array}$} & \multirow[t]{5}{*}{0,3} & $\begin{array}{l}\text { 1. Створення центру аудиту якості освіти (іншого } \\
\text { структурного підрозділу) }\end{array}$ & 0,3 \\
\hline & & $\begin{array}{l}\text { 2. Розробляння функціональних обов'язків, } \\
\text { інструкцій, графіку роботи членів центру }\end{array}$ & 0,1 \\
\hline & & 3. Створення системи навчання членів центру & 0,1 \\
\hline & & $\begin{array}{l}\text { 4. Розробляння технологій } \\
\text { аудиторських процедур }\end{array}$ & 0,1 \\
\hline & & $\begin{array}{l}\text { 5. Наявність системи контролю } \\
\text { результатів діяльності центру }\end{array}$ & 0,4 \\
\hline \multirow{3}{*}{$\begin{array}{l}\text { Результативні } \\
\text { сть системи } \\
\text { внутрішнього } \\
\text { аудиту }\end{array}$} & \multirow[t]{3}{*}{0,4} & $\begin{array}{l}\text { 1. Рівень досягнення } \\
\text { освітньої діяльності) }\end{array}$ & 0,5 \\
\hline & & 2. Рівень виконання функціональних обов’язків & 0,3 \\
\hline & & $\begin{array}{l}\text { 3. Рівень задоволеності персоналу роботою центру } \\
\text { (системою внутрішнього аудиту) }\end{array}$ & 0,2 \\
\hline
\end{tabular}

Якість внутрішнього аудиту визначають за загальноприйнятою шкалою:

- 0 - 0.6 - критичний (недостатній) рівень;

- 0,6 - 0,75- середній рівень;

- $0,75-0,9$ - оптимальний (достатній) рівень;

- $0,9-1,0-$ високий рівень.

Безумовно, ефективність шкільної системи внутрішнього аудиту залежить від професійної компетентності керівника закладу освіти. Нами проведено дослідження готовності керівників закладів загальної середньої освіти до впровадження системи внутрішнього аудиту в школі. У дослідженні взяли участь 232 керівника (директори закладів загальної середньої освіти та їх заступники), яким були запропоновані відповідні тести. Опитування дозволило 3'ясувати, що на оптимальному рівні з нормативними документами в галузі освіти знайомі 56 \% (на високому рівні $-0 \%$, на середньому - $44 \%$ ). Обгрунтовану модель системи внутрішнього аудиту надали $32 \%$ керівників. Із сучасними технологіями аналізу результатів аудиту ознайомлені лише $24 \%$ респондентів. Отже, очевидна необхідність навчання керівників закладів освіти моделювання сучасних систем внутрішнього аудиту.

Висновки. Заклади загальної середньої освіти потребують сучасної моделі внутрішнього аудиту. Необхідним є розробляння та створення центрів аудиту якості освіти (шкільної системи управління якістю освіти тощо), які мають бути забезпечені належним методичним матеріалом, інструментарієм для проведення дослідження якості освітньої діяльності та якості освіти учнів. Потребує розв’язання проблема навчання керівників закладів освіти технології внутрішнього аудиту освітньої діяльності.

\section{ЛIТЕРАТУРА}

1. Волкова Л. В. Организация внутреннего аудита в образовательной организации / Л. В. Волкова, М. А. Ефимова, Н. В. Смирнова, Е. Т. Шапкина. - Санкт-Петербург, 2017.

2. Григораш В. В. Організація діяльності керівника школи / В. В. Григораш. - Харків : Основа, 2011.

3. Житник Б. О. Управління якістю освіти: інституціальний підхід / Б. О. Житник. - Харків : Основа, 2011.

4. Касьянова О. М. Контрольно-аналітична діяльність керівника навчального закладу / О. М. Касьянова. - Харків: Основа, 2013.

5. Мониторинг образовательной системы современной школы: Учебно-методическое пособие / В. М. Антипова и др. - Ростов н/Д: Изд-во РО ИПК и ПРО, 1999.

6. Панкратова Л. А. Внутренний аудит в современной системе управления организацией / Л. А. Панкратова // Аудитор. - 2012. - № 6. - С. 25-33.

7. Фролова М. Е. Внутренний аудит как инструмент повышения качества образования / М. Е. Фролова [Электронный pecypc]. - URL : https://cyberlinka.ru/article/n/vnutrenniy-audit-kak-instrumentpovysheniya-kachestva-obrazovaniya (дата обращения: 21.08.2018). - Название с экрана.

8. Шевченко Е. С. Внутренний аудит в системе образования / Е. С. Шевченко [Электронный ресурс]. URL: http://nsportal.ru/kultura/deyatelnost/library/2015/09/11/statya-vnutrenniy-audit-v-systeme (дата обращения: 05.01.2017). - Название с экрана. 